\title{
Current situation of COVID-19 in northern Cyprus
}

Nazife Sultanoglu,,$^{1,3}$ Buket Baddal, ${ }^{1,3}$ Kaya Suer $^{2}$ and Tamer Sanlidag 3,4

${ }^{1}$ Department of Medical Microbiology and Clinical Microbiology, Faculty of Medicine, Near East University, Nicosia, Cyprus. ${ }^{2}$ Department of Clinical Microbiology and Infectious Diseases, Faculty of Medicine, Near East University, Nicosia, Cyprus. ${ }^{3}$ DESAM Institute, Near East University, Nicosia, Cyprus. ${ }^{4}$ Department of Medical Microbiology, Faculty of Medicine, Celal Bayar University, Manisa, Turkey. (Correspondence to: Nazife Sultanoglu: nazife.sultanoglu@neu.edu.tr).

\begin{abstract}
Background: The public health burden of the novel coronavirus disease 2019 (COVID-19) is expected to increase and urgent strict measures by decision-makers is critical for the containment of the novel coronavirus (SARS-CoV-2) outbreak worldwide.
\end{abstract}

Aims: This study aimed to give a real-time analysis of COVID-19 presence in northern Cyprus.

Methods: All official SARS-CoV-2 positive cases were tracked and reported in terms of the origin, nationality, and transmission routes. Preventive measures taken after the first reported case were analyzed for their effectiveness as control strategies.

Results: The index case of SARS-CoV-2 in northern Cyprus was identified as a female German tourist. First local case had travel history from the United Kingdom after which local transmission occurred. Rapid and strict containment measures have currently delayed a peak in observed cases.

Conclusions: Rapid implementation of social-distancing measures, good hygiene measures and travel/gathering bans in northern Cyprus has been effective in controlling the outbreak.

Keywords: SARS-CoV-2, COVID-19, Cyprus, surveillance, control measures

Citation: Sultanoglu N; Baddal B; Suer K; Sanlidag T. Current situation of COVID-19 in northern Cyprus. East Mediterr Health J. 2020;26(6):641-645. https://doi.org/10.26719/emhj.20.070

Received: 04/04/20; accepted: 20/05/20

Copyright @ World Health Organization (WHO) 2020. Open Access. Some rights reserved. This work is available under the CC BY-NC-SA 3.0 IGO license (https://creativecommons.org/licenses/by-nc-sa/3.o/igo).

\section{Introduction}

As of 11 March 2020, the World Health Organization (WHO) announced that the global spread of Severe Acute Respiratory Syndrome Coronavirus 2 (SARS-CoV-2) had become unstoppable and reached the required epidemiological characteristics to be declared as a pandemic (1). As of 4 May 2020, it has been confirmed that 3435894 people have been infected with SARS-CoV-2, out of which 239604 deaths have occurred. Without a doubt, one of the most affected countries has been China where the pandemic emerged in Wuhan, one of the largest cities in Hubei province, and from there spread throughout the country, with 84400 confirmed cases of SARS-CoV-2 and 4643 deaths. However, it appears that China has recently started to take control of the SARS-CoV-2 outbreak, with a declining trend of SARS-Co-V-2 cases, but the number of cases of SARS$\mathrm{CoV}-2$ continues to rise in other countries. According to the WHO Coronavirus Disease 2019 (COVID-19) Situation Report on 4 May 2020, 206299 confirmed cases and 7971 deaths had occurred in the Eastern Mediterranean Region (2). Cyprus is the third largest island in the Mediterranean with a population of approximately 375000 in the north, the majority of whom are Turkish Cypriots $(3,4)$.

\section{Methods}

All official SARS-CoV-2 positive cases were tracked and reported in terms of the origin, nationality, and trans- mission routes. Preventive measures taken after the first reported case were analyzed for their effectiveness as control strategies.

\section{Results}

The first case of SARS-CoV-2 was identified as a female German tourist on 9 March 2020, who had arrived in northern Cyprus on 8 March 2020. As a result, people who were found to have had close contact with, or tourists who had travelled on the same plane as the first patient, were exposed to SARS-CoV-2 and were quarantined in three different hotels. Shortly after the identification of the first positive case of SARS-CoV-2, precautions were enacted in northern Cyprus, which continue to be amended for the benefit of the local population (5-7). Below are the important precautions taken by the Council of Ministers with regard to the current SARS-CoV-2 outbreak in northern Cyprus to prevent further transmission. The Decisions of the Council of Ministers announced that:

- All civil workers in the public sector except for police, fire brigade, civil aviation, finance, and health workers are considered on administrative leave.

- In the private sector, all shops including casinos, nightclubs, betting offices, entertainment centres, etc., except for businesses that provide services within the 
framework of meeting basic needs such as pharmacies, gas stations, bakeries, and markets, are closed.

- Only northern Cyprus citizens and persons who have legal permission to reside in the country can enter northern Cyprus through sea, air and land border gates; entries to northern Cyprus by all other country citizens are banned.

- Regardless of which country they come from, northern Cyprus citizens and legal residents who enter the country through sea, air and land gates will be monitored and quarantined at home for 14 days. For those who do not comply with this requirement, legal action will be initiated under the Communicable Diseases Law No. 45/2018.

- Gathering in associations, unions, locales and performing collective worship are banned.

- To encourage citizens to remain in their homes, a full curfew from 21.00 to 6.00 hours is in force.

- Northern Cyprus citizens studying abroad were repatriated using charter flights, and students were quarantined for 14 days in hotels. After the 14-day quarantine period, all quarantined individuals were screened using a rapid antibody detection test. Individuals with a negative rapid test result were required to self-isolate in their homes for a further 7 days. Those with a positive rapid test result went through further confirmatory screening by polymerase chain reaction (PCR) test. These individuals were sent home if they had a negative PCR result and asked to self-isolate in their homes for a further 7 days, or were quarantined further in the case of a positive PCR result.

- After the identification of the first SARS-CoV-2 cases in Karpasia, 3 villages in Karpasia are quarantined (full curfew) and only controlled entry and exit are allowed in these villages (correct as of 27 March 2020)

- Mandatory use of face masks in public areas has been implemented by the government since 24 April 2020 (8-13).

In addition, Burhan Nalbantoglu State Hospital located in Nicosia has been fully transformed into a pandemic hospital, except for dialysis and oncology departments. Health workers will work in shifts for two weeks and will be accommodated in hotels and dormitories so as not to expose their families to the risk of infection (14).
Moreover, the 1102 Call Centre, as well as three mobile telephone numbers, were announced by the Ministry of Health as SARS-CoV-2 reporting lines. The 1102 number can be reached immediately from both landline phones and GSM operators, with more call operators commissioned to work in the call centre, where 5 calls can be taken at the same time and 10 people can be put on hold. The system has been designed to respond to callers in both Turkish and English. All citizens will be able to reach the call centre 24 hours a day, 7 days a week (15).

Although all precautions were taken rapidly, the number of SARS-CoV-2 cases identified in northern Cyprus has increased after the identification of the first case and the situation as of 4 May 2020 is summarized in Table 1. The number of cases per day after the first case (index case) was detected between 9 March 2020 and 4 May 2020 are shown in Figure 1. An increasing trend was observed after the first case was diagnosed. However, since the precautions were taken on time, the identified cases were from the same group of German tourists, since it is likely that transmission occurred in between them before the precautions were taken.

\section{Conclusion}

It is believed that as a result of the precautions that were implemented rapidly, the transmission from the German tourist group to the northern Cyprus population was prevented. No new COVID-19 cases have been detected in the country since 17 April 2020. The first SARS-CoV-2 cases involving northern Cyprus citizens had either travelled from the United Kingdom or had close contact with people who had arrived from the United Kingdom, while other cases were linked to a bus driver who had transported the German tourist group. This suggests that SARS-CoV-2 entered northern Cyprus through imported cases from Germany and the United Kingdom $(9,16-20)$. The clinical presentations at illness onset of the COVID-19 patients diagnosed in northern Cyprus were mild to severe fever, fatigue and headache (19).

As of 4 May 2020, only four COVID-19 related deaths have occurred in northern Cyprus. First patient was a 73-year-old German citizen who had chronic obstructive pulmonary disease and hypertension and was hospitalized on 20 March 2020, and subsequently transferred to an intensive care unit on 25 March 2020.

Table 1 SARS-CoV-2 cases identified in the northern Cyprus from 9 March to 4 May $2020(25,26)$

\begin{tabular}{ll} 
Total number of tests performed in northern Cyprus: & 15428 \\
Total number of positive cases: & 108 \\
Nationality: & Northern Cyprus citizens: $76 \quad$ German citizens: $31 \quad$ Turkmenistan citizen: 1 \\
Discharged patients: & 29 (German citizens) \\
& 1 (Turkmenistan citizen) \\
& 73 (Northern Cyprus citizens) \\
Ongoing treatment: & 1 Northern Cyprus citizen \\
Covid-19 related deaths: & 2 German citizens \\
& 2 northern Cyprus citizens \\
\hline
\end{tabular}




\section{Figure 1 COVID-19 surveillance in northern Cyprus between 9 March and 4 May 2020}

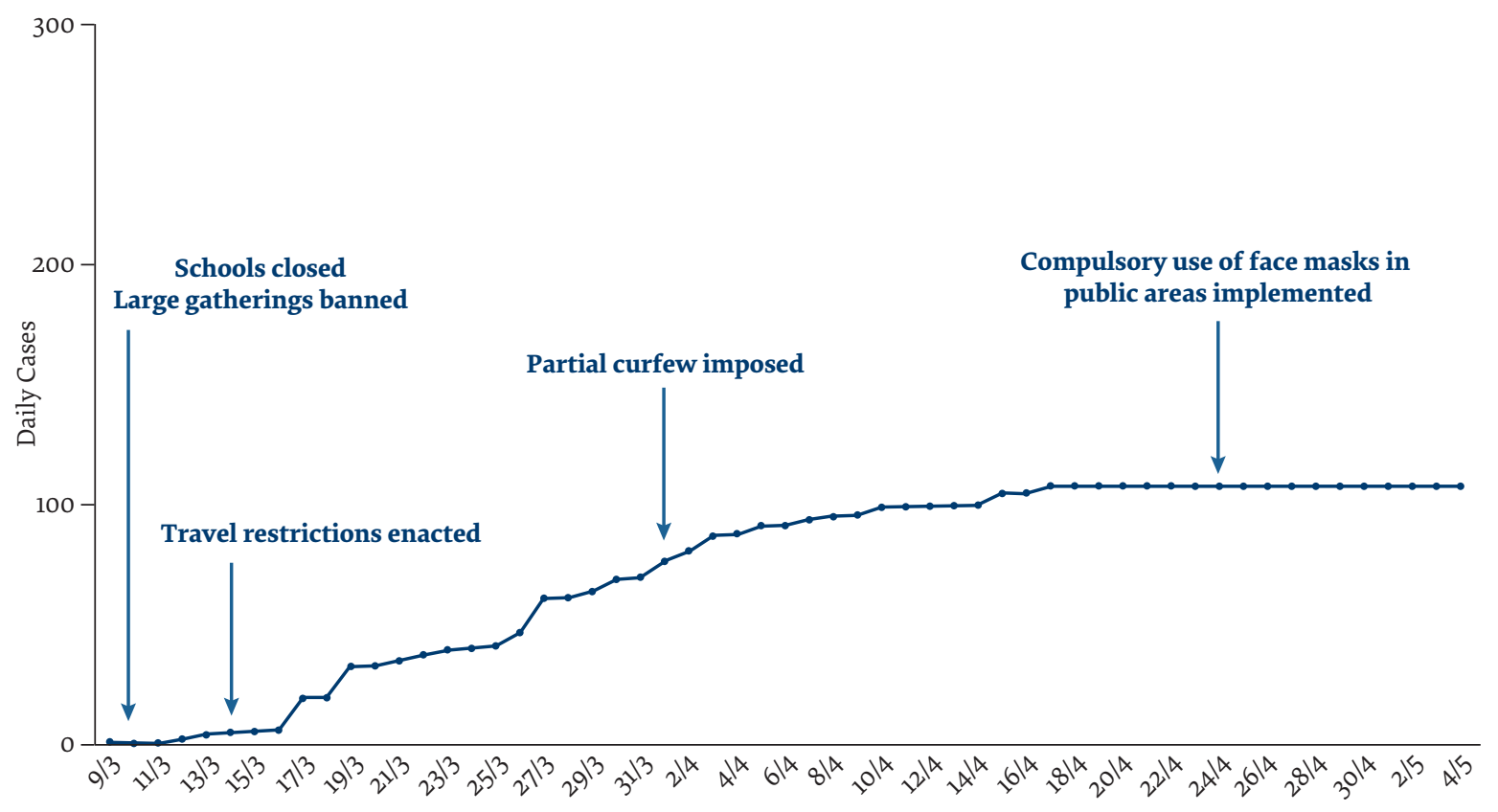

On $28 \mathrm{March}$, it was announced that this patient had died due to COVID-19-related respiratory failure and multiple organ failure.

The second patient was a German tourist, an 83-year-old female patient who also had diabetes and hypertension, and was hospitalized on 20 March 2020. She was taken into the intensive care unit on 24 March, 2020 and the death occurred on 1 April 2020. Apart from these 2 deaths, two Turkish Cypriot citizens also died due to COVID-19 - a 74-year-old male who had hypertension, diabetes and ischemic heart disease co-morbidities, and a 54-year-old male who had an underlying diabetic condition (5-7,21-24). Recently, 29 German citizens aged 65 and over from the original tourist group were discharged and sent back safely to their country. As of 4 May 2020, 103 patients have completed their treatment and recovered, with only one patient currently under treatment for COVID-19. There are no patients in the intensive care unit.

We firmly believe that northern Cyprus represents a 'good model' for other countries in the world with regard to dealing with the current COVID-19 pandemic. These stated precautions, as well as good hygiene practice, could also be used in other countries to control the further transmission of SARS-CoV-2. In addition to the precautions taken, official TV channels, universities and associations are continually sharing informative videos and information to increase awareness of the current outbreak and the role of each individual in northern Cyprus in preventing further transmission.

\section{Funding: None.}

Competing interests: None declared.

\section{Situation actuelle de la COVID-19 dans la partie nord de Chypre}

\section{Résumé}

Contexte : La charge de morbidité de la maladie à nouveau coronavirus 2019 (COVID-19) devrait augmenter. De ce fait, des mesures strictes et urgentes prises par les décideurs sont essentielles pour endiguer la flambée épidémique de nouveau coronavirus (SARS-CoV-2) dans le monde.

Objectifs : La présente étude visait à fournir une analyse en temps réel de la présence de la COVID-19 dans le nord de Chypre.

Méthodes : Tous les cas positifs officiels au SARS-CoV-2 ont été suivis et signalés en termes d'origine, de nationalité et de voies de transmission. Les mesures préventives prises après le premier cas notifié ont été analysées pour établir leur efficacité en tant que stratégies de lutte.

Résultats : Le cas indicateur de SARS-CoV-2 dans la partie nord de Chypre a été identifié comme étant une touriste allemande. Le premier cas local avait des antécédents de voyage en provenance du Royaume-Uni, ce qui a ensuite entraîné une transmission locale. Des mesures de confinement rapides et strictes ont actuellement retardé un pic dans le nombre des cas observés.

Conclusions : La mise en œuvre rapide de mesures de distanciation sociale, de bonnes mesures d'hygiène et l'interdiction de voyages/rassemblements dans la partie nord de Chypre ont été efficaces pour endiguer la flambée. 


\section{الحالة الر اهنة لكوفيد-19 في شمال قبرص \\ نظيف سلطانوجلو، بوكت بادال، كايا سوار، تامر سانليداج

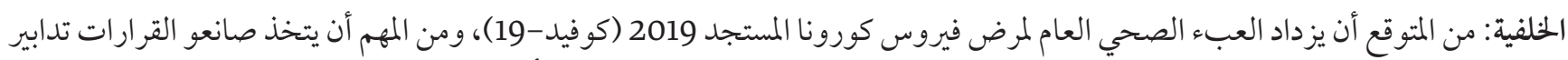

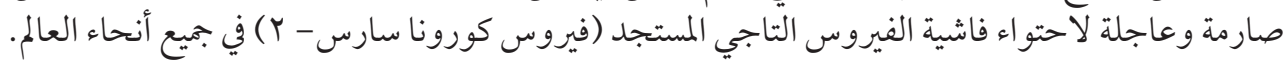

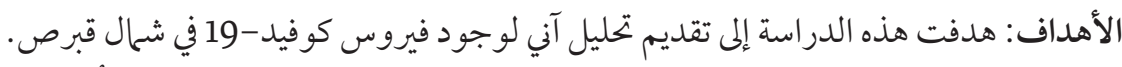

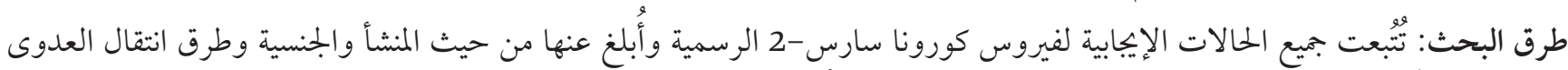

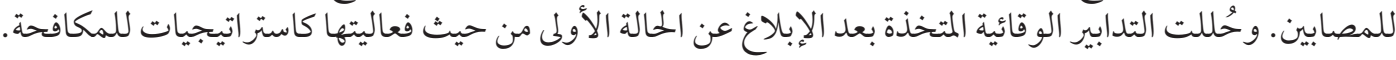

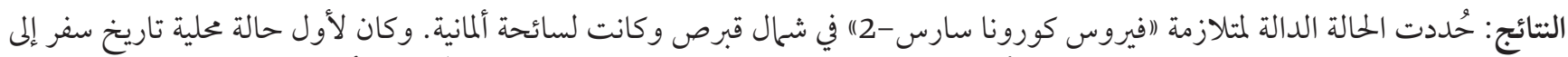

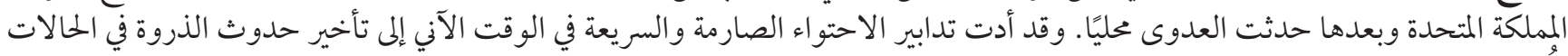
الملاحَظة.

الاستتاجات: إن التنفيذ السريع لتدابير التباعد الاجتماعي (البدني) وتدابير النظافة الصحية الجيدة وحظر السفر والتجمع في شمال قبرص كان فعالًا

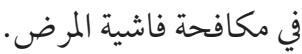

\section{References}

1. World Health Organization. WHO Director-General's opening remarks at the media briefing on COVID-19-11 March 2020. Geneva: World Health Organization; 2020. (https://www.who.int/dg/speeches/detail/who-director-general-s-opening-remarksat-the-media-briefing-on-covid-19---11-march-2020, accessed 31 March 2020).

2. World Health Organization. Coronavirus disease (COVID-19) Situation Report- 105. Geneva: World Health Organization; 2020.

3. Kliot N, Mansfield Y. The political landscape of partition: the case of Cyprus. Polit. Geogr. 1997;16(6):495-521.

4. TRNC State Planning Organization. Main site [online] (http://www.devplan.org/, accessed: 4 April 2020).

5. Turkish Republic of Northern Cyprus Ministry of Health. "It is important that our people protect themselves and take individual measures without panicking during this process.” Nicosia: Ministry of Health; 2020. (https://saglik.gov.ct.tr/Haberler/DUYURULAR/ArtMID/32470/ArticleID/123665/“Halkımızın-bu-s252re231te-panik-yapmadan-kendini-korumasi-ve-bireysel-olarak-alması-gereken-246nlemler-246nem-taşımaktadır, accessed 4 April 2020).

6. Turkish Republic of Northern Cyprus Ministry of Health. "The general health of the German patient is good, her treatment continues and is under follow-up." Nicosia: Ministry of Health; 2020. (https://saglik.gov.ct.tr/Haberler/DUYURULAR/ArtMID/32470/ArticleID/123702/“Alman-hastanın-genel-sağllk-durumu-iyi-olup-tedavisi-devam-etmektedir-ve-takip-altındadır," accessed: 4 April 2020).

7. Turkish Republic of Northern Cyprus Ministry of Health. Important explanation of the Ministry of Health. Nicosia: Ministry of Health; 2020. (https://saglik.gov.ct.tr/Haberler/DUYURULAR/ArtMID/32470/ArticleID/123979/SAĞLIK-BAKANLIĞI-214NEMLI-A199IKLAMA, accessed 4 April 2020).

8. Turkish Republic of Northern Cyprus Ministry of Health, "Minister Pilli: "With the statement of WHO, we immediately started preparations for a possible Corona virus outbreak," Nicosia: Ministry of Health; 2020. (https://saglik.gov.ct.tr/Haberler/ DUYURULAR/ArtMID/32470/ArticleID/123618/Bakan-Pilli-DS214'n252n-a2311klamas1-ile-birlikte-olas116oKorona-vir252s-salg1nına-y246nelik-hazırlıklara16ohemen-başladık, accessed 4 April 2020).

9. Turkish Republic of Northern Cyprus Ministry of Health. Ministry of Health Important Announcement. Nicosia: Ministry of Health; 2020. (https://saglik.gov.ct.tr/Haberler/DUYURULAR/ArtMID/32470/ArticleID/12406o/Sağlık-Bakanlığı-214nemli-Duyuru, accessed 4 April 2020).

10. Turkish Republic of Northern Cyprus Ministry of Health, Council of Ministers decisions on Corona Virus. Nicosia: Ministry of Health; 2020 (https://saglik.gov.ct.tr/Haberler/DUYURULAR/ArtMID/32470/ArticleID/124142/Korona-Vir252s-ile-ilgili-Bakanlar-Kurulu-kararları, accessed 4 April 2020).

11. Turkish Republic of Northern Cyprus Ministry of Health, "Minister Pilli: 'It is a legal obligation for every person coming to our country to keep themselves in isolation for 14 days from the date of entering TRNC." Nicosia: Ministry of Health; 2020. (https:// saglik.gov.ct.tr/Haberler/DUYURULAR/ArtMID/32470/ArticleID/124235/Bakan-Pilli-22olkemize-gelecek-her-kişinin-KKTC'yegiriş-yaptığı-tarihten-itibaren-14-g252n-s252re-ile-kendilerini-evlerinde-izolasyon-altında-tutmaları-bir-yasal-zorunluluktur, accessed 4 April 2020).

12. Turkish Republic of Northern Cyprus Ministry of Health. Announcement of the Ministry of Health. Nicosia: Ministry of Health; 2020. (https://saglik.gov.ct.tr/Haberler/DUYURULAR/ArtMID/32470/ArticleID/125343/Sağlık-Bakanlığı-Duyuru, accessed 4 April 2020). 
13. "It is mandatory to wear a mask from today." Havadis Newspaper- Cyprus News, 5 May 2020 (https://www.havadiskibris.com/ bugunden-itibaren-maske-takmak-zorunlu/, accessed 5 May 2020).

14. Turkish Republic of Northern Cyprus Ministry of Health. "Pilli: 'Nalbantoglu turns into Pandemi Hospital." Nicosia: Ministry of Health; 2020 (https://saglik.gov.ct.tr/Haberler/DUYURULAR/ArtMID/32470/ArticleID/125541/Pilli-"Nalbantoğlu-Pandemi16oHastanesi'ne-d246n252ş252yor, accessed 4 April 2020).

15. Turkish Republic of Northern Cyprus Ministry of Health. Call Center Numbered 1102 Commissioned. Nicosia: Ministry of Health; 2020. (https://saglik.gov.ct.tr/Haberler/DUYURULAR/ArtMID/32470/ArticleID/124147/1102-Numaral1-199ağr1-Merkezi-Devreye-Girdi, accessed 4 April 2020).

16. [16] Turkish Republic of Northern Cyprus Ministry of Health. Ministry of Health Description. Nicosia: Ministry of Health; 2020. (https://saglik.gov.ct.tr/Haberler/DUYURULAR/ArtMID/32470/ArticleID/124007/Sağllk-Bakanlığı-A2311klama, accessed 4 April 2020).

17. Turkish Republic of Northern Cyprus Ministry of Health. The number of cases increased to 6 in the TRNC! Nicosia: Ministry of Health; 2020. (https://saglik.gov.ct.tr/Haberler/DUYURULAR/ArtMID/32470/ArticleID/124245/KKTC'de-vaka-sayıs1-6'ya-2311kt1, accessed 4 April 2020).

18. Turkish Republic of Northern Cyprus Ministry of Health. Important Notice from the TRNC Ministry of Health. Nicosia: Ministry of Health; 2020. (https://saglik.gov.ct.tr/Haberler/DUYURULAR/ArtMID/32470/ArticleID/124273/Sağllk-Bakanlığg'ndan214nemli-Duyuru-Important-Notice-from-the-TRNC-Ministry-of-Health, accessed 4 April 2020).

19. Turkish Republic of Northern Cyprus Ministry of Health. Ministry of Health Statement - Number of Cases increased to 20. Nicosia: Ministry of Health; 2020. (https://saglik.gov.ct.tr/Haberler/DUYURULAR/ArtMID/32470/ArticleID/124484/Sağlık-Bakanlığı-A2311klama, accessed 4 April 2020).

20. Turkish Republic of Northern Cyprus Ministry of Health. 12 German Tourists and 1 TRNC Citizen Positive. Nicosia: Ministry of Health; 2020. (https://saglik.gov.ct.tr/Haberler/DUYURULAR/ArtMID/32470/ArticleID/124662/12-Alman-Turist-ve-1-KKTCVatandaşı-Pozitif, accessed 4 April 2020).

21. Turkish Republic of Northern Cyprus Ministry of Health. To the knowledge of the public! Nicosia: Ministry of Health; 2020. (https://saglik.gov.ct.tr/Haberler/DUYURULAR/ArtMID/32470/ArticleID/125477/Kamuoyunun-bilgisine, accessed 4 April 2020).

22. Turkish Republic of Northern Cyprus Ministry of Health, "Explanation of the Ministry of Health - 2nd death. Nicosia: Ministry of Health; 2020. (https://saglik.gov.ct.tr/Haberler/ArtMID/31973/ArticleID/125802/SAĞLIK-BAKANLIĞI-ACIKLAMA, accessed 4 April 2020).

23. "Third death in TRNC due to Corona virus." Havadis Newspaper, Cyprus News, 5 May 2020 (https://www.havadiskibris.com/ kktcde-corona-virus-nedeniyle-3uncu-olum/, accessed 5 May 2020).

24. Postası K. 4th death in TRNC due to coronavirus. Kibripostasi, 5 May 2020. (https://www.kibrispostasi.com/c35-KIBRIS_HABERLERI/n319959-kktcde-koronavirusten-dolayi-4-olum, accessed 5 May 2020).

25. Turkish Republic of Northern Cyprus Ministry of Health, "Minister Pilli: '1419 tests in total, no positive cases,"'2020. [Online]. Available:https://saglik.gov.ct.tr/Haberler/DUYURULAR/ArtMID/32470/ArticleID/129374/Bakan-Pilli-Toplam-1419-test-yapıld1pozitif-vaka-yok.[Accessed: 09-Jun-2020].

26. H. Kibris, "Another coronavirus casein TRNC!,” 2020. [Online]. Available:https://haberkibris.com/kktcde-bir-kiside-daha-korona-virus-vakasi-2315-2020-03-26.html.[Accessed: 09-Jun-2020 